\title{
Quarry Mud as Partial Replacement for Fine Combination (Sand) in Concrete
}

\author{
Sp. Aswinpalaniappan ${ }^{*}$, G. Panneerselvam² \\ ${ }^{1}$ Dept. of Civil Engineering, Sri Raaja Raajan College of Engineering \& Technology Karaikudi, Tamilnadu, India \\ ${ }^{2}$ Dept. of Civil Engineering, Alagappa Chettiar College of Engineering \& Technology Karaikudi, Tamilnadu, India \\ Email: *aswinpls@gmail.com
}

How to cite this paper: Aswinpalaniappan, S. and Panneerselvam, G. (2018) Quarry Mud as Partial Replacement for Fine Combination (Sand) in Concrete. Open Access Library Journal, 5: e4529.

https://doi.org/10.4236/oalib.1104529

Received: March 20, 2018

Accepted: April 23, 2018

Published: April 26, 2018

Copyright $\odot 2018$ by authors and Open Access Library Inc.

This work is licensed under the Creative Commons Attribution International License (CC BY 4.0).

http://creativecommons.org/licenses/by/4.0/

(c) (i) Open Access

\begin{abstract}
Concrete production has resulted inside the accumulated that has to be compelled to confirm substitute material to sand as inside the assembly of concretes. Quarry mud, a by-product from the crushing methodology throughout production activities is one in each of such materials. Granite fines or rock mud can be a by-product obtained throughout crushing of granite rocks to boot observed as quarry mud. In recent days, there have been additionally several trials to use ash, academic degree industrial by product as partial replacement for cement to possess higher workability, future strength and to make the concrete lots of economically accessible. This gift work could be a trial to use Quarry mud as partial replacement for sand in concrete. Trials are created to review the properties of concrete and to research some properties of Quarry mud, the standard of those properties to alter them to be used partial replacement materials for sand in concrete.
\end{abstract}

\section{Subject Areas \\ Civil Engineering}

\section{Keywords}

Quarry Mud, Red Mud, Compressive Strength

\section{Introduction}

Concrete is that the foremost well-liked physical object inside the planet. However, the assembly of cement has diminished the stone reserves inside the planet and desires a decent consumption of energy. Watercourse sand has been the foremost trendy choice for the fine combination of a part of concrete within the past, but overuse of the material has semiconductor unit to environmental issues, the depleting of securable watercourse sand deposits and a concomitant 
increment inside the fabric. Thus the quarry dirt has been planned as another watercourse sand that provides additional profit to concrete quarry dirt which is believed to increase the strength of concrete over concrete created with equal quantities of rivers sand, but it causes a reduction inside the workability of concrete.

\section{Materials Used}

\subsection{Ordinary Cement}

The cement that is used is of OPC fifty 3 grade as per the standard of the country [1] [2] and [3]. The cement in step with the Indian specification ought to satisfy the IS code IS 12269-1987 (reaffirmed 1999). Is commonest kind if cement usually use around the world, used as a basic ingredient of concrete, mortar, stucco, and most non-specialty grout.

It was developed from different sorts of hydraulic lime in European nation at intervals the center nineteenth century and generally originates from stone. In may be a fine power created by heating material terribly\} very kitchen appliance to from what is spoken as clinker, grinding the clinker and adding small amounts of other materials. several sorts of cement square measure offered, with the foremost common being spoken as traditional cement (OPC) that's gray in color, but a white cement is in addition offered (Table 1$)$.

\subsection{Fine Combination}

The natural fine combination are the watercourse sand that's that the foremost commonly used, but the recent social issue that created a shortage of the material created a wonderful disadvantage among the development sector [4] [5]. For the studies the watercourse sand of zone-II is utilized in all the references (Table 2).

\subsection{Coarse Combination}

The material that is maintained on IS sieve no. 4.75 is termed as a rough combination.

Table 1. Ordinary cement property.

\begin{tabular}{cccc}
\hline \multirow{2}{*}{ SI. No. } & \multicolumn{3}{c}{ Ordinary Cement Property } \\
\cline { 2 - 4 } & Property & Initial & Result \\
\hline 1 & Normal consistency & NC & $33 \%$ \\
2 & Initial setting time & IST & $30 \mathrm{~min}$ \\
3 & Specific gravity & SG & 3.15 \\
4 & Fines of cement & FC & $3200 \mathrm{~cm}^{2} / \mathrm{gm}^{2}$ \\
\hline
\end{tabular}

Table 2. Fine combination property.

\begin{tabular}{cccc}
\hline \multirow{2}{*}{ SI. No. } & \multicolumn{3}{c}{ Fine Combination Property } \\
\cline { 2 - 4 } & Property & Initial & Result \\
\hline 1 & Specific gravity & SG & 2.57 \\
2 & Fineness modulus & FM & 2.28 \\
3 & Grading zone & GZ & II \\
\hline
\end{tabular}


The crushed stone is mostly used as a rough combination. The character of labor decides the most size of the coarse combination. Regionally out there coarse combination having the most size of $20 \mathrm{~mm}$ was employed in this work. The combinations were washed to get rid of dirt and dirt and were dried to surface dry condition. The combinations were tested as per IS: 383-1970 (Table 3).

\section{Quarry Mud/Dust}

The Quarry dirt is that the waste product collected from rock mines as are |they're\} known as rock waste as these days this dirt was used for darting over recently paved road therefore on create the surface straightforward to usable these are fine sized particles that has identical properties as that compared to sand therefore this may be used for replacement the sand in concrete chosen from the closest supply as raw materials with none process of the dust from the quarry.

\subsection{Origin of Quarry Dirt}

The quarry dirt is that the waste product from rock mines because the blasting of rock produces smaller particles as waste this waste was utilized in covering the recently paved road. The finer the dirt what's from mines collected from close to by areas.

\subsection{Blessings of Quarry Dirt}

The specific gravity depends on the character of the rock from that it is processed and therefore the variation is a smaller amount. It's higher fines modulus therefore makes easier bonding between concrete.

\subsection{Collection of Quarry Dirt}

The quarry dirt is waste product from rock mine business close to pudukottai and tanjavur district wherever there square measure an outsized variety of rock mining business gift therefore there'll be enough merchandise out there for production as a reality we have a tendency to square measure assembling the dirt directly from the waste and conducting tests required for decisive the properties of it there'll great amount of dirt out there conjointly for big production. As we have a tendency to square measure assembling the merchandise because it state of nature with none testing's and admixtures square measure to that.

Table 3. Coarse aggregate property.

\begin{tabular}{cccc}
\hline \multirow{2}{*}{ SI. No. } & \multicolumn{3}{c}{ Coarse Aggregate Property } \\
\cline { 2 - 4 } & Property & Initial & Result \\
\hline 1 & Size & $\mathrm{S}$ & $20 \mathrm{~mm}$ \\
2 & Total water absorption & TWA & $0.705 \%$ \\
3 & Specific gravity & SG & 2.74 \\
4 & Fineness modulus & FM & 7.20 \\
\hline
\end{tabular}




\section{Would Like for the Replacement of Sand}

Large scale efforts square measure needed for reducing the usage of the staple that square measure gift, so giant replacement is finished mistreatment the varied by-product material that square measure out there within the gift day. the opposite material that may be used is quarry dirt that is created whereas within the process of the granite stone into combination, this fashioned as a fine dirt within the crushers that method the aggregates The properties of concrete in contemporary and hardened state square measure the studied within the varied paper that square measure used as a reference for this. a number of the properties square measure workability, compressive strength square measure the most important one that square measure thought of.

\subsection{Water}

Water is a vital ingredient of concrete because it actively strength giving cement gel, the number and quality of water is needed to be looked into terribly carefully.

\subsection{Physical and Chemical Properties}

The physical and chemical properties of quarry dirt obtained by testing the sample as per the Indian standards square measure listed within Table 4 \& Table 5.

Table 4. Physical properties of quarry dust and natural sand.

\begin{tabular}{cccc}
\hline \multirow{2}{*}{ Property } & \multicolumn{2}{c}{ Physical properties of quarry dust and natural sand } \\
\cline { 2 - 4 } & Quarry dust & Natural sand & Test method \\
\hline Specific gravity & $2.54-2.60$ & 2.60 & IS 2386 (part III)-1963 \\
Bulk density $\left(\mathrm{kg} / \mathrm{m}^{3}\right)$ & $1720-1810$ & 1460 & IS 2386 (part III)-1963 \\
Absorption (\%) & $1.20-1.50$ & nil & IS 2386 (part III)-1963 \\
Moisture content (\%) & Nil & 1.50 & IS 2386 (part III)-1963 \\
Fine particles less then 0.075 mm (\%) & $12-15$ & 6 & IS 2386 (part III)-1963 \\
Sieve analysis & Zone-II & Zone-II & IS 383-1970 \\
\hline
\end{tabular}

Table 5. Chemical properties of quarry dust and natural sand.

\begin{tabular}{cccc}
\hline \multirow{2}{*}{ Constituents } & \multicolumn{3}{c}{ Chemical properties of quarry dust and natural sand } \\
\cline { 2 - 4 } & Quarry dust & Natural sand & Test method \\
\hline $\mathrm{SiO}_{2}$ & 62.48 & 80.78 & IS 4032-1968 \\
$\mathrm{Al}_{2} \mathrm{O}_{3}$ & 18.72 & 10.52 & IS 4032-1968 \\
$\mathrm{Fe}_{2} \mathrm{O}_{3}$ & 6.54 & 1.75 & IS 4032-1968 \\
$\mathrm{CaO}$ & 4.83 & 3.21 & IS 4032-1968 \\
$\mathrm{MgO}$ & 2.56 & 0.77 & IS 4032-1968 \\
$\mathrm{Na}_{2} \mathrm{O}$ & $\mathrm{Nil}$ & 1.37 & IS 4032-1968 \\
$\mathrm{K}_{2} \mathrm{O}$ & 3.18 & 1.23 & IS 4032-1968 \\
$\mathrm{TiO}_{2}$ & 1.21 & Nil & IS 4032-1968 \\
Loss of ignition & 0.48 & 0.37 & IS 4032-1968 \\
\hline
\end{tabular}




\subsection{Properties of Material}

\section{MATERIALPROPERTIES}

Crushed granite stone Max size: $20 \mathrm{~mm}$;

Specific gravity: 2.98;

Fineness modules: 6.36;

Density: $1.58 \mathrm{gm} / \mathrm{cc}$;

River sand Specific gravity: 2. 53;

Fineness modules: 3.08;

Density: $1.63 \mathrm{gm} / \mathrm{cc}$;

Void radio: 0.55;

Quarry dust Specific gravity: 2.57;

Fineness modules: 2.41;

Density: $1.85 \mathrm{gm} / \mathrm{cc}$;

Void radio: 0.42;

Ordinary Portland cement Specific gravity: 3.05;

Initial setting time: $30 \mathrm{~min}$;

Final setting time: $220 \mathrm{~min}$;

Fineness: $8 \%$ residue on IS 90 micro sieve.

\section{Design Procedure}

\subsection{Mixing}

Mixing of concrete desires careful condition to avoid segregation and therefore the problem of blending the materials uniformly. Increase within the ratio, volume proportion, size and amount of coarse combination intensity difficulties and balling tendencies.

The object of blending is that the concrete mass becomes homogenized and uniform in color and consistency. All the mixture particles ought to have a price of cement past and every one the ingredients of the concrete ought to mix into a regular mass.

Mixing of concrete could also be done by one in every of the traditional strategies of hand combination (or) machine combination. But it's necessary to own a regular dispersion and combination constituents to forestall segregation or balling throughout combination.

The quantity of ingredients for the preparation of cubs is little thence during this project hand combination is adopted.

\subsection{Casting}

The check cube specimens are created once combination and such away on manufacture full compaction of the concrete with neither segregation nor excessive laitance. The concrete is crammed into the cube mould. In putting every scoop jam-packed with concrete, the highest fringe of the mould because the concrete slide from it, so as to every by hand or by vibration. Once the highest layer has been compacted the surface is delivered to the finished level with the highest of the cube mould employing a trowel. 
The standard tamper is employed and therefore the strokes of the bar distributed during a uniform manner over the cross section of mould. The stroke penetrate into the underneath lying layer and therefore the bottom layer is required.

\subsection{Concrete Cube Made by Using Quarry Dust}

The concrete cubes are prepared by using replacement of $10 \%, 20 \%$, and $30 \%$ of quarry dust. These cubes are tested for compressive strength at 3, 7 and 14 days. Three cube specimens were tested at 3, 7, and 14 days in each percentage and obtained the compressive strength.

\section{Testing of Material}

\subsection{Specific Gravity for Quarry Dust Material}

\section{Procedure:}

Dry the pycnometer/density bolte and weight with its cap tightly screwed on. Let it be w1. Unscrewed the cap and put in the quarry dust material. Let it be w2.

Add sufficient amount of water to cover the quarry dust material about halfull and screw on top. Shake the pycnometer well and remove entrapped air if any.

Repeat the procedure for their sample and obtain the average values of specific gravity (Table 6, Figure 1).

Table 6. Specific gravity for quarry dust material.

\begin{tabular}{cccc}
\hline & \multicolumn{4}{c}{ Specific gravity for quarry dust material } \\
SI. No. & Specification & TRIAL-1 & TRIAL-2 \\
\cline { 2 - 4 } & Empty weight of pycnometer (W1) & $0.612 \mathrm{~kg}$ & $0.610 \mathrm{~kg}$ \\
2 & Empty weight of pycnometer + quarry dust (W2) & $1.316 \mathrm{~kg}$ & $1.310 \mathrm{~kg}$ \\
3 & Empty weight of pycnometer + quarry dust + water (W3) & $1.900 \mathrm{~kg}$ & $1.897 \mathrm{~kg}$ \\
4 & Empty weight of pycnometer + water (W4) & $1.486 \mathrm{~kg}$ & $1.480 \mathrm{~kg}$ \\
\hline
\end{tabular}

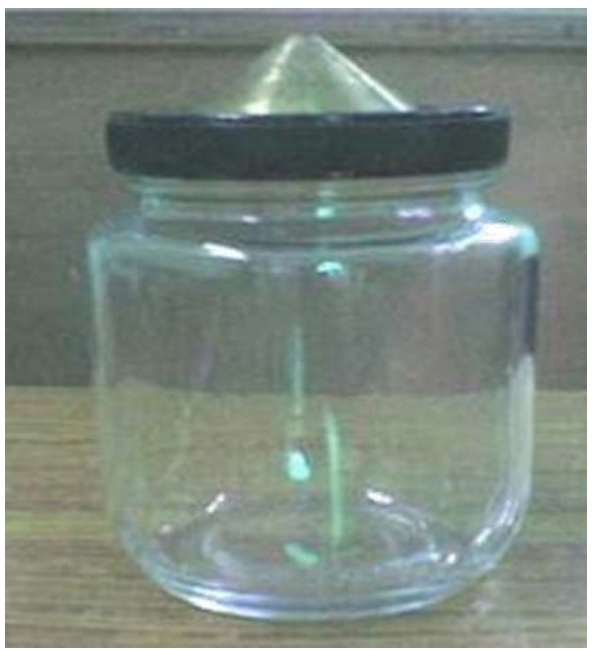

Figure 1. Pycnometer. 


\section{Observation:}

- $\mathrm{W} 1=$ Empty weight of pycnometer;

- $\mathrm{W} 2$ = Empty weight of pycnometer + quarry dust;

- $\mathrm{W} 3=$ Empty weight of pycnometer + quarry dust + water;

- $\mathrm{W} 4=$ Empty weight of pycnometer + water.

Calculation:

$$
\begin{aligned}
\text { Specific gravity } & =(\mathrm{W} 2-\mathrm{W} 1) /((\mathrm{W} 2-\mathrm{W} 1)-(\mathrm{W} 3-\mathrm{W} 4)) \\
& =(1.316-0.612) /(1.316-0.612)-(1.900-1.486) \\
& =2.42 \%
\end{aligned}
$$

Result:

Specific gravity of quarry dust material $=2.42 \%$.

\subsection{Fineness for Quarry Dust Material}

\section{Procedure:}

The about 100 gms of quarry dust material in the sieve 90 micron. Then place the sieve in the sieve shaker and switch on the sieve shaker. After 15 min we have to switch off the sieve shaker. Then we have to switch note the material retained in the sieve. Then using the below formula we have to find out the percentage of the quarry dust material (Table 7).

Result:

Fineness of quarry dust material $=2.67 \%$.

\subsection{Bulk Modulus of Quarry Dust}

\section{Procedure:}

Bulking is a major problem while mixing the concrete. A measuring jar is taken and sad is filled up-to a mark in the measuring jar.

Then water is added up to the highest mark in the vessel and left it for settling and the settled height is measured and the percentage bulking is calculated (Table 8).

Result:

The bulk modulus of given material $=238 \mathrm{~g}$.

\subsection{Workability of Quarry Dust Material}

\section{Procedure:}

- The workability is one of the physical parameter of concrete which affect the strength and durability and the appearance of the finished surface. If the water absorption capacity if the aggregates.

- In our case we have used slump cone test for measuring the workability of concrete.

- We have measured the height of the fall of the cone of concrete for various water cement radio and recorded the value for ordinary concrete (Table 9).

Then the same procedure is done with the concrete having the partial 
Table 7. Fineness for quarry dust material.

\begin{tabular}{cccc}
\hline \multirow{3}{*}{ SI. No. } & \multicolumn{3}{c}{ Fineness for Quarry Dust Material } \\
\cline { 2 - 4 } & Weight of sample in gm & Weight of residue \% & Fineness in gm \\
\hline 1 & 100 & 4 & 4 \\
2 & 100 & 3 & 3 \\
3 & 100 & 3 & 3 \\
\hline
\end{tabular}

Table 8. Bulk modulus of quarry dust.

\begin{tabular}{cccc}
\hline & \multicolumn{3}{c}{ Bulk modulus of quarry dust } \\
\cline { 2 - 4 } SI. No. & Volume of quarry dust & Water absorption of quarry dust & $\begin{array}{c}\text { Time taken of } \\
\text { absorption }\end{array}$ \\
\hline 1 & $200 \mathrm{~g}$ & $238 \mathrm{~g}$ & $10 \mathrm{~min}$ \\
\hline
\end{tabular}

Table 9. Workability of quarry dust material.

\begin{tabular}{cccc}
\hline \multirow{2}{*}{ Weight of cement } & \multicolumn{3}{c}{ Workability of quarry dust material } \\
\cline { 2 - 4 } & Water cement ratio & Volume of water & Slump in (mm) \\
\hline 1 & $2000 \mathrm{~g}$ & 0.50 & $900 \mathrm{ml}$ \\
2 & $2000 \mathrm{~g}$ & 0.55 & $1100 \mathrm{ml}$ \\
3 & $2000 \mathrm{~g}$ & 0.60 & $1300 \mathrm{ml}$ \\
\hline
\end{tabular}

replacement of sand with raw quarry dust at various percentages.

\section{Result:}

The slump value of concrete is $=120 \mathrm{~mm}$. Therefore, the slump is true slump.

\subsection{Fineness for Sand}

\section{Procedure:}

The about 100 gms of quarry dust material in the sieve 90 micron.

Then place the sieve in the sieve shaker and switch on the sieve shaker. After 15 min we have to switch off the sieve shaker. Then we have to switch note the material retained in the sieve. Then using the below formula we have to find out the percentage of the quarry dust material (Table 10).

\section{Result:}

Fineness of sand $=2.67 \%$.

\subsection{Fineness of Cement}

\section{Procedure:}

- Weight accurately $100 \mathrm{gm}$ of cement in a china dish.

- Place it on a standard IS 90 micron sieve.

- The sieve in both the hand.

- Breakout any air set lumps ion cement sample with figure (Figures 2-7).

- Weight the residue of sieving accurately.

- Repeat the procedure three such samples (Table 11). 


\section{Calculation:}

Fineness value $=($ weight of residue $/$ weight of cement $) \times 100$

$$
\begin{aligned}
& =3 / 100 \times 100 \\
& =3 \% \\
& =(3+2+2) / 3 \\
& =2.33 \%
\end{aligned}
$$

Table 10. Fineness for sand.

\begin{tabular}{cccc}
\hline \multirow{2}{*}{ SL. No. } & \multicolumn{3}{c}{ Workability of quarry dust material } \\
\cline { 2 - 4 } & Weight of sample in gm & Weight of residue in \% & Fineness in gm \\
\hline 1 & 100 & 4 & 4 \\
2 & 100 & 3 & 3 \\
3 & 100 & 3 & 3 \\
\hline
\end{tabular}

Table 11. Fineness of cement.

\begin{tabular}{cccc}
\hline & \multicolumn{3}{c}{ Fineness of cement } \\
\cline { 2 - 4 } SL. No. & Weight of cement in gm & Weight of residue in $\%$ & Fineness in cement \\
\hline 1 & 100 & 3 & 3 \\
2 & 100 & 2 & 2 \\
3 & 100 & 2 & 2 \\
\hline
\end{tabular}

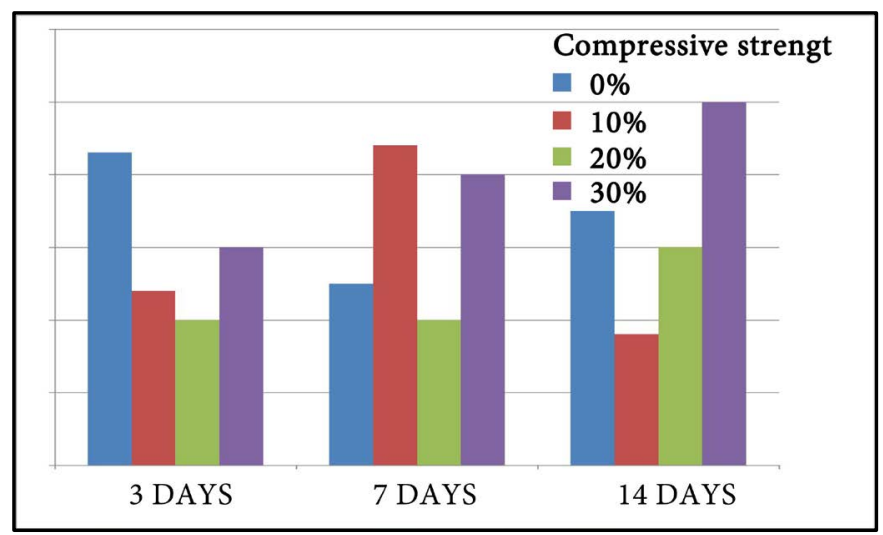

Figure 2. Compressive strength chart.

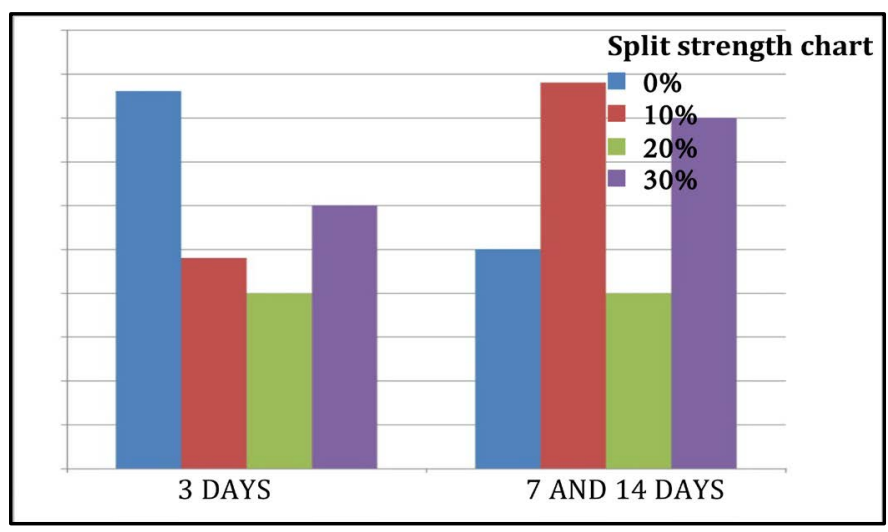

Figure 3. Split strength chart. 


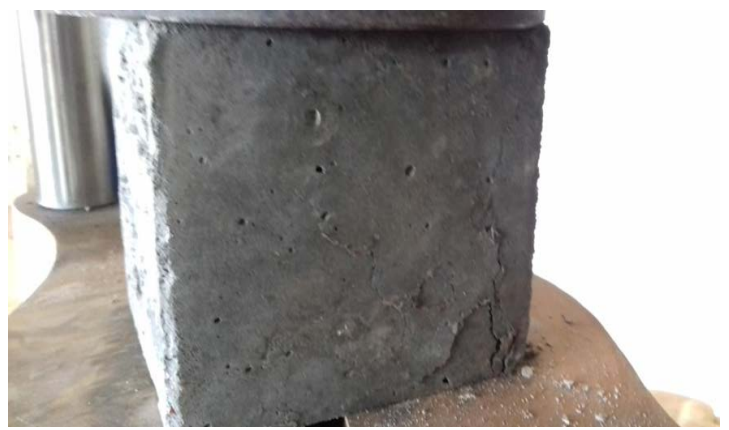

Figure 4. Compressive strength test for 3 days curing.

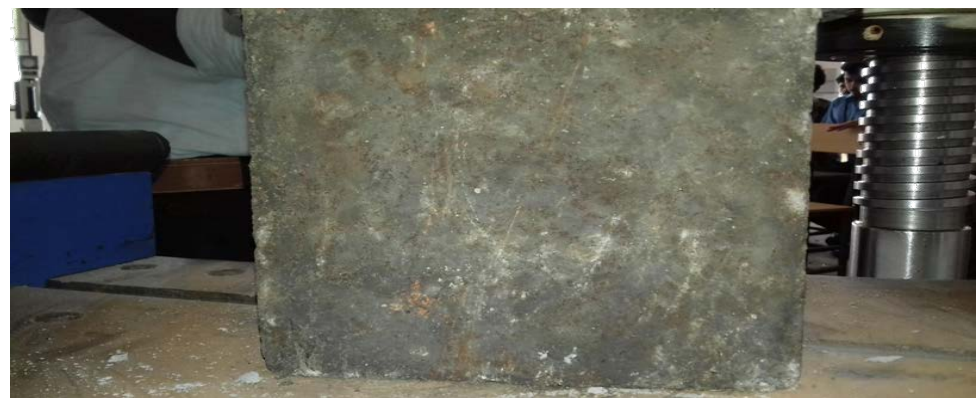

Figure 5. Compressive strength test for 14 days curing.

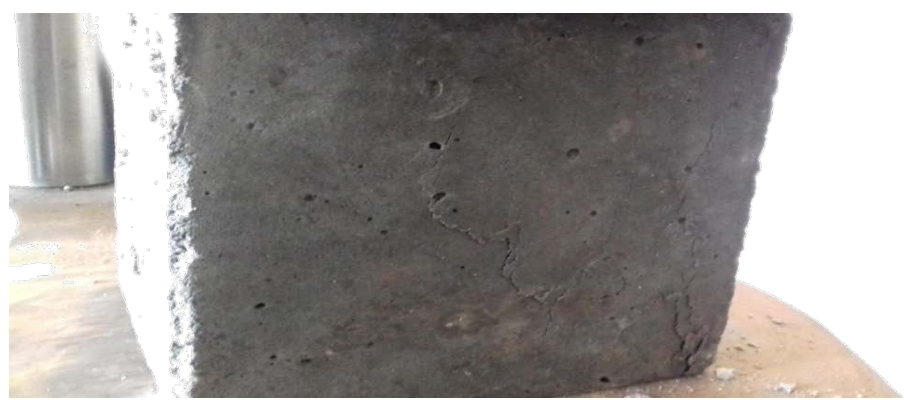

Figure 6. Compressive strength test for 21 days curuing.

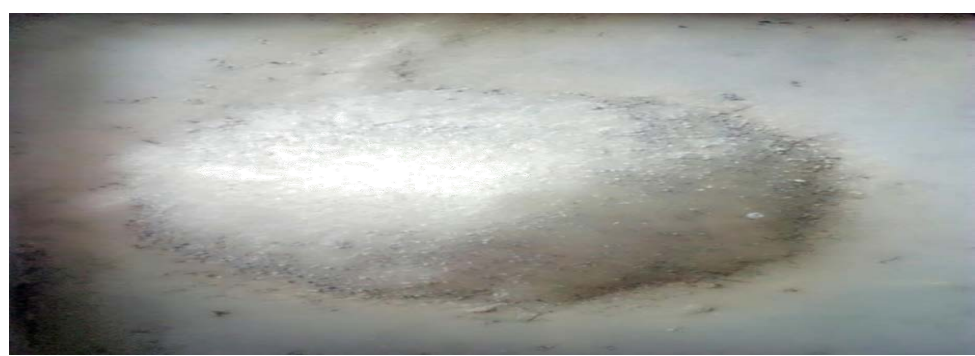

Figure 7. Quarry mud.

\section{Result:}

Fineness of cement $=2.33 \%$.

\subsection{Specific Gravity of Cement}

Observation (Table 12):

- $\mathrm{W} 1$ = Empty weight of pycnometer; 
- $\mathrm{W} 2$ = Empty weight of pycnometer + cement;

- $\mathrm{W} 3=$ Empty weight of pycnometer + cement + water;

- W4 = Empty weight of pycnometer + water.

Calculation:

$$
\begin{aligned}
\text { Specific gravity } & =(\mathrm{W} 2-\mathrm{W} 1) /((\mathrm{W} 2-\mathrm{W} 1)-(\mathrm{W} 3-\mathrm{W} 4)) \\
& =(258-131) /(258-131)-(454-366) \\
& =3.15
\end{aligned}
$$

\section{Result:}

Specific gravity of cement material $=3.15$.

\subsection{Specific Gravity of Sand}

\section{Procedure:}

- Dry the pycnometer/density bolte and weight with its cap tightly screwed on. Let it be w1. Unscrewed the cap and put in the quarry dust material. Let it be w2.

- Add sufficiend amount of water to cover the sand material about halfull and screw on top. Shake the pycnometer well and remove entrapped air if any.

- Repeat the procedure for there sample and obtain the average values of specific gravity.

Observation (Table 13):

- $\mathrm{W} 1$ = Empty weight of pycnometer;

- $\mathrm{W} 2$ = Empty weight of pycnometer + sand;

- $\mathrm{W} 3$ = Empty weight of pycnometer + sand + water;

- $\mathrm{W} 4=$ Empty weight of pycnometer + water.

Table 12. Specific gravity of cement.

\begin{tabular}{cccc}
\hline \multirow{2}{*}{ SI. No. } & \multicolumn{3}{c}{ Specific gravity for quarry dust material } \\
\cline { 2 - 4 } & Specification & Weight & TRIAL-1 \\
\hline 1 & Empty weight of pycnometer & (W1) & 131 \\
2 & Empty weight of pycnometer +cement & (W2) & 258 \\
3 & Empty weight of pycnometer + cement + water & (W3) & 454 \\
4 & Empty weight of pycnometer + water & (W4) & 366 \\
\hline
\end{tabular}

Table 13. Specific gravity of sand.

\begin{tabular}{cccc}
\hline \multirow{2}{*}{ SI. No. } & \multicolumn{2}{c}{ Specific gravity for quarry dust material } \\
\cline { 2 - 4 } & Specification & Weight & TRIAL-1 \\
\hline 1 & Empty weight of pycnometer & (W1) & 670 \\
2 & Empty weight of pycnometer + sand & (W2) & 1221 \\
3 & Empty weight of pycnometer + sand + water & (W3) & 1869 \\
4 & Empty weight of pycnometer + water & (W4) & 1544 \\
\hline
\end{tabular}




\section{Calculation:}

$$
\begin{aligned}
\text { Specific gravity } & =(\mathrm{W} 2-\mathrm{W} 1) /((\mathrm{W} 2-\mathrm{W} 1)-(\mathrm{W} 3-\mathrm{W} 4)) \\
& =(1221-670) /(1221-670)-(1860-1544) \\
& =2.59
\end{aligned}
$$

\section{Result:}

Specific gravity of sand material $=2.59$.

\subsection{Specific Gravity of Coarse Aggregate}

\section{Procedure:}

Dry the pycnometer/density bolte and weight with its cap tightly screwed on. Let it be w1. Unscrewed the cap and put in the quarry dust material. Let it be w2.

Add sufficient amount of water to cover the coarse aggregate material about Hal full and screw on top. Shake the pycnometer well and remove entrapped air if any.

Repeat the procedure for there sample and obtain the average values of specific gravity (Table 14).

\section{Observation:}

- $\mathrm{W} 1=$ Empty weight of pycnometer;

- $\mathrm{W} 2$ = Empty weight of pycnometer + coarse aggregate;

- W3 = Empty weight of pycnometer + coarse aggregate + water;

- $\mathrm{W} 4=$ Empty weight of pycnometer + water.

\section{Calculation:}

$$
\begin{aligned}
\text { Specific gravity } & =(\mathrm{W} 2-\mathrm{W} 1) /((\mathrm{W} 2-\mathrm{W} 1)-(\mathrm{W} 3-\mathrm{W} 4)) \\
& =(817-484) /(817-484)-(1342-1123) \\
& =2.75
\end{aligned}
$$

Result:

Specific gravity of coarse aggregate material $=2.75$.

\section{Concrete Mix Design (Table 15)}

\section{(M 20 GRADE)}

\section{Test data for materials:}

1) Specific gravity of cement $=3.24$;

2) Specific gravity of coarse aggregate $=2.75$;

3) Specific gravity of sand $=2.6$;

4) Water absorption $=8 \%$;

5) Coarse aggregate $=0.50 \%$;

6) Sand $=1.00$.

\section{Target mean strength:}

The target mean strength for specified characteristic cube strength is

Fck1 $=$ Fck +1.68 s;

$\mathrm{S}=4.0$ (is 106262; Table 1$)$.

$$
\begin{aligned}
\text { Fckl } & =20+(1.65 \times 4) \\
& =26.6 \mathrm{~N} / \mathrm{mm}^{2} .
\end{aligned}
$$


Table 14. Specific gravity of coarse aggregate.

\begin{tabular}{cccc}
\hline \multirow{2}{*}{ SI. No. } & \multicolumn{3}{c}{ Specific gravity for quarry dust material } \\
\cline { 2 - 4 } & Specification & Weight & TRIAL-1 \\
\hline 1 & Empty weight of pycnometer & (W1) & 484 \\
2 & Empty weight of pycnometer + CA & $(\mathrm{W} 2)$ & 817 \\
3 & Empty weight of pycnometer + CA + water & $(\mathrm{W} 3)$ & 1342 \\
4 & Empty weight of pycnometer + water & $(\mathrm{W} 4)$ & 1123 \\
\hline
\end{tabular}

Table 15. Mix proportion.

\begin{tabular}{cccc}
\hline \multirow{2}{*}{ Cement } & \multicolumn{3}{c}{ Specific gravity for quarry dust material } \\
\cline { 2 - 4 } & Fine Aggregate & Course Aggregate & W/C ratio \\
\hline 0.156 cum & 0.304 cum & $0.496 \mathrm{cum}$ & 0.55 \\
1 & 1.95 & 3.18 & 0.55 \\
\hline
\end{tabular}

\section{Water-cement ratio:}

$\mathrm{W} / \mathrm{C}$ ratio for $\mathrm{M} 20$ concrete $=0.55$ ( Table 5 : is 456 ).

\section{Water content:}

Water content for $20 \mathrm{~mm}$ for 25 - 50 slump $=186$ liters.

\section{Cement content:}

$\mathrm{W} / \mathrm{C}$ ratio $=0.55$.

Mass of cement needed $=$ water cement $/ 5.5$

$$
\begin{aligned}
& =372 \mathrm{~kg} \text { of cement } \\
& =7.5 \text { bags of cement. }
\end{aligned}
$$

\section{Water cement ratio:}

Water cement ratio for M20 concrete $=0.55$ (Table 5; is 456).

Water content for $20 \mathrm{~mm}$ for 25 - $50 \mathrm{~mm}$ slump = 186 litres (Table 2; is 10262)

$$
\begin{aligned}
\mathrm{w} / \mathrm{c} & =0.55 \\
& =0.55 \times 0.95 \\
& =0.470 \mathrm{lit}
\end{aligned}
$$

\section{Material calculation:}

Mix ratio $\mathrm{M} 20=1: 1.9: 3.1$

$$
\begin{aligned}
\text { volume of cube } & =0.15 \times 0.15 \times 0.15 \\
& =3.375 \times 10^{-3} \mathrm{~m}^{3}
\end{aligned}
$$

Density of unit weight of cement $=1440 \mathrm{~kg} / \mathrm{m}^{3}$

$$
\begin{aligned}
& \begin{aligned}
\text { volume } & =1 / \mathrm{mc} \times \text { volume } \times \text { density } \\
& =1 / 5.10 \times\left(3.375 \times 10^{-3}\right) \times 1440 \\
& =0.95
\end{aligned} \\
& \begin{aligned}
\text { cement }=1 \times 0.95=0.95 \mathrm{~kg} \\
\text { sand }=1.9 \times 0.95=1.80 \mathrm{~kg}
\end{aligned} \\
& \text { coarse agg }=3.1 \times 0.95=2.94 \mathrm{~kg}
\end{aligned}
$$

\section{Coarse aggregate proportion:}

M20 grade, zone ii from Table 5. 
Proportion for $0.5 \mathrm{w} / \mathrm{c}$ ratio.

Coarse aggregate proportion $=0.62$ (Table 3 is 10262).

Coarse aggregate content:

total aggregate $=1-$ volume of cement - volume of water

$$
\begin{aligned}
& =1-(\mathrm{mc} / 1000 \mathrm{sc})-(\mathrm{mw} / 1000 \mathrm{sw}) \\
& =1-(372 / 1000 \times 3.15)-(186 / 1000 \times 1) \\
& =1-0.1181-0.186 \\
& =0.6959 \mathrm{cu} . \mathrm{m} \\
& =0.62 \times 0.6959 \times 2.74 \times 1000 \\
& =1182 \mathrm{~kg} \text { of coarse aggregate } \\
& =0.38 \times 0.6959 \times 2.74 \times 1000 \\
& =725 \mathrm{~kg} \text { of fine aggregate }
\end{aligned}
$$

GRADE M20 ratio.

\section{Replacement of fine aggregate}

- FOR 10\% OF REPLACEMENT = $(10 / 100) \times(1800)=180 \mathrm{gm} ;$

- FOR 20\% OF REPLACEMENT $=(20 / 100) \times(1800)=360 \mathrm{gm}$;

- FOR 30\% OF REPLACEMENT $=(30 / 100) \times(1800)=540 \mathrm{gm}$. Compressive strength and split tensile strength (Table 16).

\section{Conclusions}

- Organization of favor and making of concrete cubes for testing are that the key for the success of this project.

- Protection of natural resources sand from extinction is that the foremost

\begin{tabular}{|c|c|c|c|}
\hline \multirow{2}{*}{$\%$ of quarry added in } & \multicolumn{3}{|c|}{ Compressive Strength Curing days } \\
\hline & 7 & 14 & 21 \\
\hline 30 & 30 & 30 & 30 \\
\hline 10.2 & 10.2 & 10.2 & 10.2 \\
\hline 21.1 & 21.1 & 21.1 & 21.1 \\
\hline \multirow[t]{2}{*}{26.5} & 26.5 & 26.5 & 26.5 \\
\hline & \multicolumn{3}{|c|}{ Split tensile strength } \\
\hline$\%$ of quarry added in & Curing days & 14 & 21 \\
\hline 30 & 30 & 2.6 & 2.6 \\
\hline 10.2 & 10.2 & 2.9 & 2.9 \\
\hline 21.1 & 21.1 & 2.8 & 2.8 \\
\hline 26.5 & 26.5 & 3 & 3 \\
\hline
\end{tabular}
important wish of the implementation of this project.

- It is important that every natural resource got to be saved for future so as that we've an inclination to take sand.

- Completion of this project can result in a simply out there replacement and a main quality concrete.

- This project was done on the sphere by making concrete cubes and curing

Table 16. Compressive strength and split tensile strength. 
them within the traditional water as we have a tendency to waste traditional concrete thus on not modification the essential nature and easily out there one.

- The project offers an excellent result as that quarry dirt could be another by product that could be rock dirt naturally accrued which can assist in place of sand and have analogous properties as of sand.

- As a result, we've an inclination to successfully find a replacement material for sand in concrete as per Indian standards.

\section{Acknowledgements}

The author's at the outset would like to express his abundant to Dr. A. ELANGO, Principal, Alagappa Chettiar College of Engineering and Technology, Karaikudi, and his indebtedness to Prof. G. PANNEERSELVAM, Professor and Head of Civil Engineering, Alagappa Chettiar College of Engineering and Technology, Karaikudi, for providing him an opportunity to do research in the College and extending invaluable guidance throughout this paper work.

Prof. G. PANNEERSELVAM's dynamism, vision, sincerity, motivation and approach have deeply inspired author. He has taught author the methodology to carry out the research and to present "paper works" as clearly as possible. It was a great privilege and honor to work and study under an able teacher.

I am extending my thanks to Thiru A. Dharanidharan, Asst. Professor Department of Civil Engineering, Alagappa Chettiar College of Engineering and Technology, Karaikudi, for his guidance during my research work.

I owe a lot to all the staff of the Department of Civil Engineering, Alagappa Chettiar College of Engineering and Technology, Karaikudi, for their kindness and readiness in offering a helping hand during my stumbling.

I thank the management of Sri Raaja Raajan College of Engineering, Karaikudi for their support to do this work. My sincere thanks to my Principal Dr. A. Kumaravadivel, Prof. I. Rasheed Khan, Professor and Head of Civil Engineering, for their genuine and moral support at Sri Raaja Raajan College of Engineering and Technology, Karaikudi, to complete this research paper work successfully. As a student of Sri Raaja Raajan College of Engineering and Technology, Karaikudi, I bow my head in reverence.

I am extending my thanks to my parents for their supporting hand during my research work.

Finally, my gratefulness to all those people who have supported me to complete this research work directly or indirectly.

\section{References}

[1] Abou-Zeid, M.N. and Fakhry, M.M. (2003) Short-Term Impact of High Aggregate Fines Content on Concrete Incorporating Water-Reducing Admixtures. ACI Materials Journal, 100, 280-285.

[2] Ahmed Ahmed, E. and Ahemed Kourd, A.E. (1989) Properties of Concrete Incorporating Natural and Crushed Stone Very Fine Sand. ACI Material Journal, 86, 
417-424.

[3] Ahn, N. (2000) An Experimental Study on the Guidelines for Using Higher Contents of Aggregate Microfines in Portland Cement Concrete. PhD Dissertation, University of Texas, Austin.

[4] Ahn, N. and Fowler, D.W. (2001) An Experimental Study on the Guidelines for Using Higher Contents of Aggregate Microfines in Portland Cement Concrete. International Center for Aggregates Research, Research Report ICAR 102-1F, 435.

[5] Ahn, N. and Fowler, D.W. (2002) The Effects of High Fines on the Properties of Concrete. ICAR 10th Annual Symposium: Aggregates Asphalt Concrete, Portland Cement Concrete, Bases and Fines, 14-17 April 2002, Baltimore, 15 p. 